\title{
Pengaruh Pelatihan, Motivasi Kerja, dan Lingkungan Kerja Terhadap Kinerja Guru di Yayasan AL-Muniroh Ujung Pangkah Gresik
}

\author{
Twovindarista Permatasari \\ Program Studi Manajemen Fakultas Ekonomi dan Bisnis \\ Universitas Muhammadiyah Gresik, Jawa Timur,Indonesia \\ Email: twovindarista1997@gmail.com \\ Alkusani \\ Program Studi Manajemen Fakultas Ekonomi dan Bisnis \\ Universitas Muhammadiyah Gresik, Jawa Timur, Indonesia \\ Email: alkusani13@gmail.com
}

\begin{abstract}
The Influence of training, Work motivation, Work environment on teacher performance at the foundation AL-Muniroh Ujung Pangkah Gresik, using saturated sampling method is a sampling technique when all members of the population are used as samples. This is done because the population is too small and the researcher wants to make generalizations with a small error rate of 76 teacher. The data analysis technique used multiple liniear regression analysis. The result showed that training, work motivation, and work environment partially significant influence on the performance of the AL-Muniroh Ujung Pangkah Gresik Foudation teacher.
\end{abstract}

Keywords: Training, Work Motivation, Work Environment, and Teacher Performance

\section{Pendahuluan}

Masalah pendidikan adalah masalah yang sangat penting dalam kehidupan, baik kehidupan keluarga atau berbangsa dan bernegara. Maju mundurnya suatu bangsa sangat di pengaruhi oleh kondisi pendidikanya, Indonesia telah berusaha meningkatkan mutu pendidikan pada semua jenis dan jenjang pendidikan, tetapi usaha tersebut masih banyak mengalami kendala, terutama dalam upaya peningkatan mutu sekolah.

Banyak masalah mutu yang dihadapi dalam dunia pendidikan, misalnya mutu lulusan, mutu sarana dan prasarana pendidikan, mutu pembelajaran, mutu profesionalan dan kinerja guru, mutu-mutu tersebut terkait dengan mutu manajerial para pimpinan pendidikan serta dukungan dari pihak pihak yang terkait dengan pendidikan. Semua kelemahan mutu dari komponen pendidikan tersebut akhirnya berujung pada rendahnya mutu lulusan. 


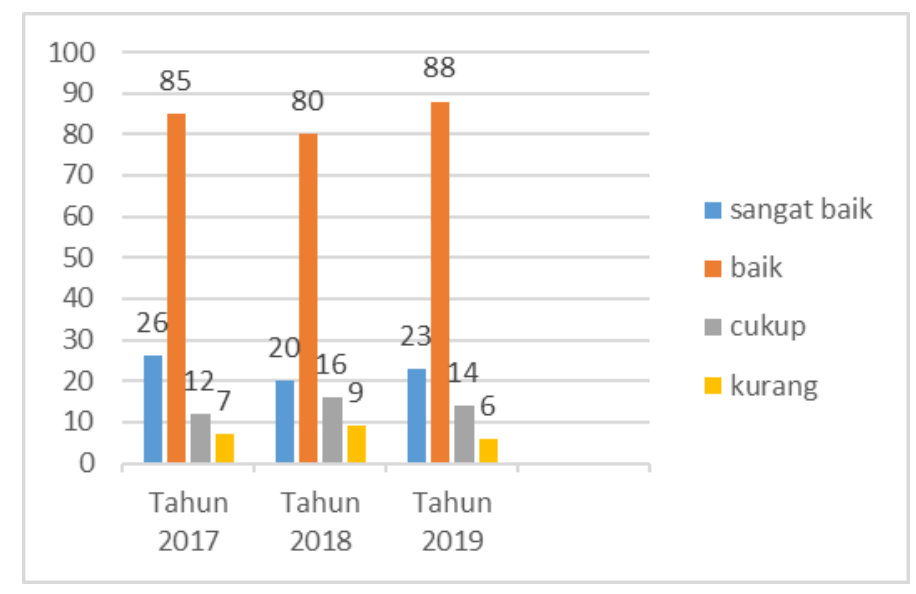

Gambar 1.1

Kinerja Guru Mts AL-Muniroh Ujung Pangkah Gresik Tahun 2017-2019

Sumber. Tata Usaha MTS AL-Muniroh Ujung Pangkah Gresik

Berdasarkan data pada gambar 1.1 di atas menunjukan bahwa dari mulai tahun 20172019 kinerja guru di Mts AL-Muniroh Ujung Pangkah Gresik tidak pernah mencapai skala ini yang telah ditentukan yaitu 100\%, pada tahun 2017 sampai dengan 2019 mengalami penurunan dan kenaikan kinerja. Tahun 2017 kinerja guru hanya mencapai rata-rata nilai baik yaitu 85\%, pada tahun 2018 ada penurunan sebesar 80\%, dan pada tahun 2019 mengalami kenaikan kinerja dengan rata-rata nilai sebesar $88 \%$ hal ini menunjukan bahwa kinerja guru di Mts AL-Muniroh Ujung Pangkah Gresik mengalami penurunan dan kenaikan setiap tahunya, dengan jumlah siswa 481.

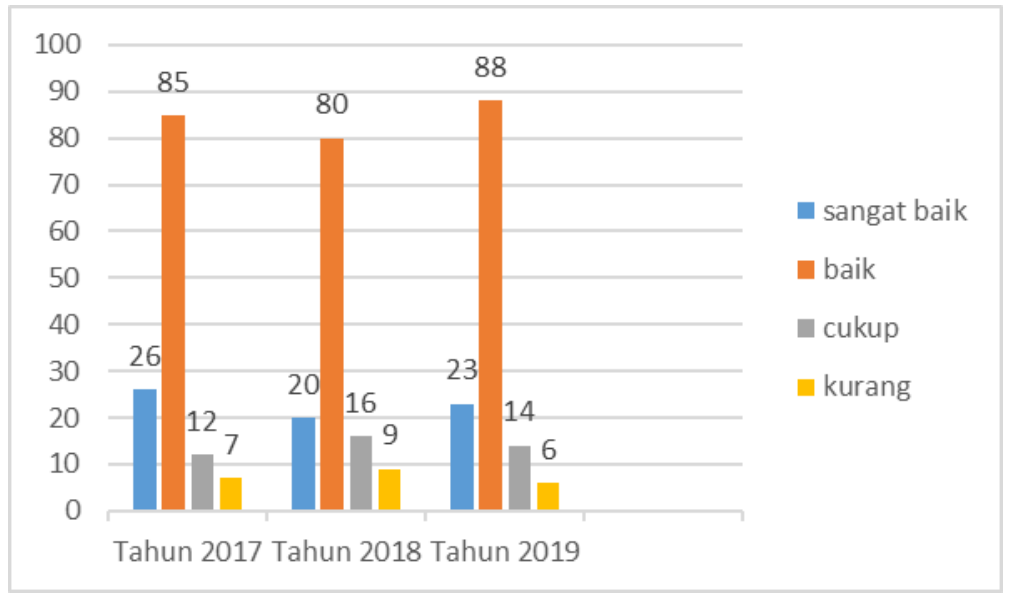

Gambar1.2

Kinerja Guru Ma AL-Muniroh Ujung Pangkah Gresik

Sumber : Tata Usaha Ma AL-Muniroh Ujung Pangkah Gresik 
Berdasarkan data pada gambar 1.2 tersebut diatas menunjukan bahwa dari mulai tahun 2016-2019 kinerja guru di Ma AL-Muniroh tidak pernah mencapai skala nilai yang telah dotentukan yaitu 100\%, pada tahun 2016 sampai dengan 2019 terus mengalami kenaikan hingga penurunan kinerja. Tahun 2016 kinerja guru hanya mencapai rata-rata nilai baik 89\%, dan pada tahun 2017 nilai rata-rata kinerja guru mengalami penurunan yaitu menjadi 87\% pada tahun 2018 tidak ada peningkatan maupun penurunan pada kinerja guru yaitu $87 \%$ rata-rata yang didapatkan pada tahun 2018 sama dengan rata-rata nilai yang didapatkan pada tahun 2017. Penurunan kinerja guru pada tahun 2019 sampai dengan ratarata nilai $89 \%$ hal ini menunjukan bahwa kinerja guru di MA AL-Muniroh Ujung Pangkah Gresik mengalami kenaikan hingga penurunan setiap tahunya, dengan jumlah siswa sebanyak 447 siswa.

\section{Kajian Teori}

\section{Pelatihan}

Menurut Nawari (2011:208) Pengertian pelatihan adalah program-program untuk memperbaiki kemampuan melaksanakan secara individual, kelompok dan berdasarkan jenjang jabatan dalam organisasi atau perusahaan. Pengertian lain mengatakan pelatihan adalah proses melengkapi para pekerja dengan keterampilan khusus atau kegiatan membantu para pekerja dalam memperbaiki pelaksanaan pekerja yang tidak efisien. Tujuan utamanya untuk melengkapi kemampuanya kerjanya, agar mampu melaksanakan tugas-tugas secara efektif dan efisien.

H1: Pelatihan berpengaruh secara parsial terhadap kinerja guru.

\section{Motivasi Kerja}

Menurut Afandi (2016:12) motivasi meliputi perasaan unik, pikiran, dan pengalaman masa lalu yang merupakan bagian dari hubungan internal dan eksternal sedemikian pentinya motivasi, banyak ahli filsafat, sosiolog, psikolog, maupun ahli manajemen melakukan penelitian.

H2: Motivasi Kerja berpengaruh secara parsial terhadap kinerja guru.

\section{Lingkungan Kerja}

Menurut Afandi, (2016:51) Lingkungan Kerja adalah segala sesuatu yang ada disekitar dan dapat mempengaruhi dalam menjalankan tugas yang dibebankan kepadanya misalnya dengan adanya air conditioner (AC), penerangan memadai dan sebagainya. Lingkungan kerja adalah sesuatu yang ada dilingkungan para pekerja yang dapat mempengaruhi dalam menjalankan tugas seperti temperature, kelembapan, ventilasi, 
penerangan, kegaduan, kebersihan, tempat kerja dan memadai tidaknya alat-alat perlengkapan kerja. Lingkungan kerja adalah sesuatu yang ada disekitar para pekerja yang dapat mempengaruhi kepuasan kerja dalam melaksanakan pekerjaanya sehingga akan diperoleh hasil kerja yang maksimal, dimana dalam lingkungan kerja tersebut terdapat fasilitas kerja yang mendukung dalam peneyelesaian tugas yang bebankan kepada guru guna menungkatkan kerja guru.

H3: Lingkungan Kerja berpengaruh secara parsial terhadap kinerja guru.

\section{Kinerja Guru}

Menurut Priansa (2011:196) menyatakan bahwa kinerja merupakan hasil yang dicapai seorang menurut ukuran yang berlaku, dalam kurun waktu tertentu, berkenan dengan pekerjaan serta perilaku dan tindakanya.

\section{Kerangka Konseptual}

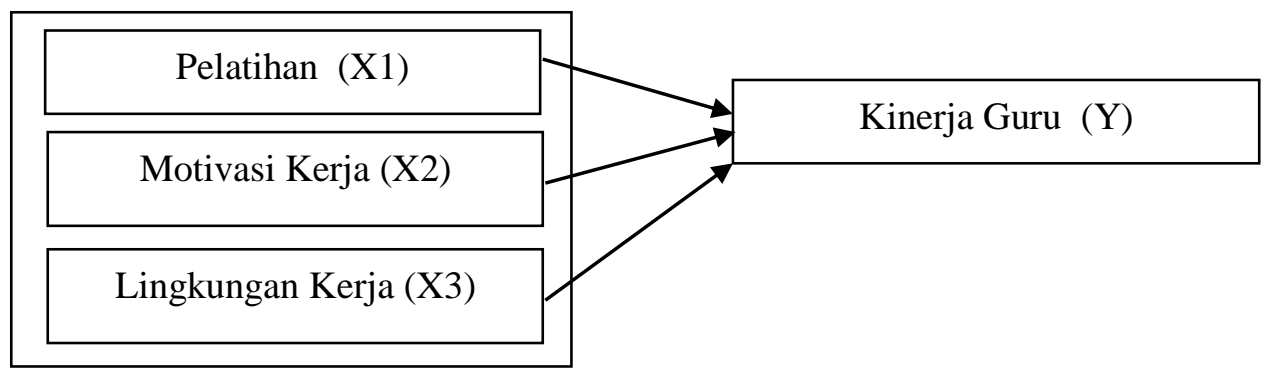

Gambar 2.1

Kerangka Konseptual

Keterangan : $\longrightarrow$ Secara Parsial

\section{Metode Penelitian}

\section{Pendekatan dan Lokasi Penelitian}

Pendekatan penelitian ini adalah penelitian Kuantitatif.Lokasi penelitian ini dilakukan di Jln. Pendidikan Pangkah Wetan Ujung Pangkah Gresik, Jawa Timur 61154.

\section{Populasi dan Sampel}

Menurut Sugiyono (2017:80) populasi adalah wilayah generalisasi yang terdiri atas objek/subjek yang mempunyai kualitas dan karakteristik teretentu yang ditetapkan oleh peneliti untuk dipelajari dan kemudian ditarik kesimpulannya. Populasi dari penelitian ini adalah seluruh Guru di Mts dan Ma Yayasan AL-muniroh Ujung Pangkah Gresik semua 
berjumlah 76 Pegawai tahun 2020.

Menurut Sugiyono $(2017 ; 118)$ sampel adalah bagian dari jumlah dan karakteristik yang dimiliki oleh populasi. Sampel pada penelitian ini adalah Guru di Mts dan Ma ALMuniroh Ujung Pangkah Gresik. Untuk menentukan sampel peneliti ini mengambil seluruh dari total populasi yaitu berjumlah 76 orang pegawai.

\section{Jenis dan Sumber Data}

Teknik pengumpulan data dalam penelitian ini adalah kuisioner. Menurut sugiyono (2017:199) kuisioner merupakan teknik pengumpulan data yang dilakukan dengan cara member seperangkat pertanyaan atas penyataan tertulis kepada responden untuk dijawabnya. Dalam penelitian ini peneliti langsung terjun kelapangan guna mendapatkan jawaban responden yang dijadikan sebagai sampel penelitian.

\section{Teknik Pengambilan dan Analisis Data}

Dalam penelitian ini digunakan teknik analisis regresi linear berganda (analisis jalur) karena dapat menerangkan ketergantungan variabel terkait dengan satu atau lebih bebas. Dalam analisis ini dapat diukur hubungan antara satu variabel terikat dengan satu variabel bebas. Teknik analisis data yang digunakan dalam penelitian ini adalah analisis regresi linear berganda.Analisis regresi berganda menunjukkan hubungan variabel independen yaitu Pelatihan (X1), Motivasi Kerja (X2), dan Lingkungan Kerja (X3) terhadap variabel dependen Kinerja Guru (Y).

$$
\mathrm{Y}=\alpha+\beta 1 \mathrm{X} 1+\beta 2 \mathrm{X} 2+\beta 3 \mathrm{X} 3+\mathrm{e}
$$

\section{Hasil Penelitian}

\section{Uji Instrumen}

\section{Uji Validitas}

Pada penelitian ini menggunakan kuesioner untuk mengumpulkan data peneliain. Suatu kuisioner dikatakan valid jika pertanyaan pada kuisioner mampu untuk mengungkapkan sesuatu yang akan diukur oleh kuisioner tersebut, uji validitas isi suatu butir pernyataan atau variabel dikatakan valid jika $r_{\text {hitung }}$ lebih besar dari $r_{\text {tabel }}$.

\section{Tabel 2}

\section{Rekapitulasi Hasil Uji Validitas Instrumen Penelitian}

\begin{tabular}{|c|l|c|c|l|}
\hline variabel & Item/pertanyaam & R hitung & $\mathrm{R}$ tabel & Keterangan \\
\hline $\mathrm{X} 1$ & $\mathrm{X} 1.1$ & 0,807 & 0,2257 & Valid \\
\hline
\end{tabular}




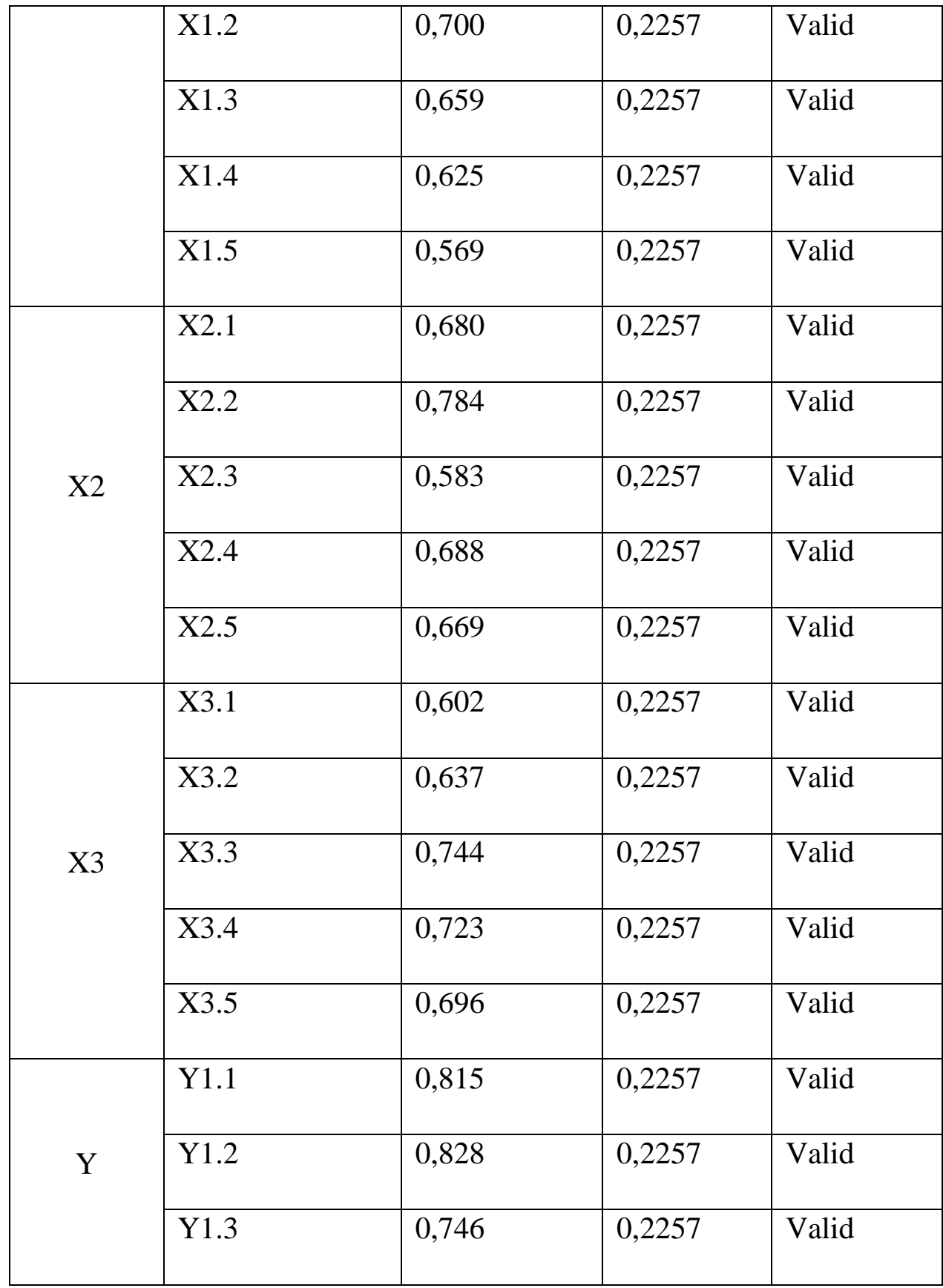

\section{Sumber: Lampiran 4}

Berdasarkan Tabel hasil Uji Validitas dapat diketahui bahwa seluruh item (indikator) masing-masing Variabel yaitu Variabel Pelatihan $\left(\mathrm{X}_{1}\right)$, Motivasi Kerja $\left(\mathrm{X}_{2}\right)$, Lingkungan Kerja $\left(\mathrm{X}_{3}\right)$, dan Kinerja Guru (Y). Hasil $r_{\text {hitung }}>r_{\text {tabel }}$ 0,2257, maka seluruh butir pernyataan dari variabel independent dan dependent terbukti valid.

\section{Uji Reliabilitas}

Reliabilitas dikatakan reliabilitas apabila memiliki nilai Cronbach Alfa $(\alpha)>0,70$, (Ghozali, 2016:48). Berdasarkan hasil perhitungan yang dilakukan dengan aplikasi SPSS 21.0, pengujian reliabilitas pada penelitian ini ditunjukan pada Tabel berikut : 
Tabel 4.10

Hasil Uji Reliabilitas Instrumen Penelitian

\begin{tabular}{|c|c|c|c|}
\hline Variabel & Cronbach's Alpha & Alpha & Keterangan \\
\hline Y & 0,703 & 0,70 & Reliabel \\
\hline X1 & 0,714 & 0,70 & Reliabel \\
\hline X2 & 0,710 & 0,70 & Reliabel \\
\hline X3 & 0,713 & 0,70 & Reliabel \\
\hline
\end{tabular}

Sumber: Lampiran 4

Berdasarkan Tabel 3 Hasil uji reliabilitas dapat diketahui bahwa nilai Cronbach Alpha lebih besar dari 0,70, maka seluruh kuisioner yang digunakan dalam penelitian ini reliabel.

\section{Uji Asumsi Klasik}

\section{Uji Normalitas}

Menurut Ghozali (2016:154) uji normalitas bertujuan untuk menguji apakah dalam model regresi, variabel pengganggu atau residual memiliki distribusi normal. Uji normalitas yang digunakan dalam penelitian ini adalah uji Kolmogorov-Smirnov dengan hipotesis sebagai berikut (Ghozali, 2016:158).

Tabel 4.11

Hasil Uji Kolmogorov-Smirnof test

One-Sample Kolmogorov-Smirnof Test

\section{One-Sample Kolmogorov-Smirnov Test}

\begin{tabular}{|ll|l|}
\hline & $\begin{array}{l}\text { Unstandardi } \\
\text { zed } \\
\text { Residual }\end{array}$ \\
\hline $\mathrm{N}$ & Mean & 76 \\
Normal Parameters & Std. \\
& Deviation & 1.0000000 \\
&
\end{tabular}




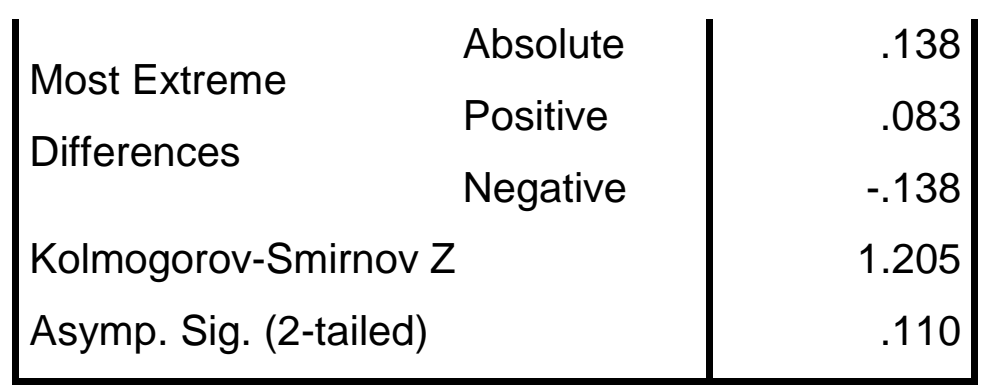

a. Test distribution is Normal.

b. Calculated from data.

Data hasil uji asumsi klasik untuk menguji normalitas yaitu menggunakan uji Kolomogrov-Smirnov (K-S) didapatkan Besarnya nilai Signifikan 0,110 yang lebih besar dari Alpha 0,05 Hasil tersebut menunjukan bahwa residual berdistribusi normal.

\section{Uji Multikolineritas}

Uji multikolinearitas dalam penelitian ini dengan menggunakan dasar pengambilan keputusan, Jika nilai Variance Inflation Factor (VIF) tidak lebih dari 10 dan nilai Tolerance (TOL) tidak kurang dari 0,1, maka model dapat dikatakan terbebas dari multikolinearitas (Ghozali, 2016:23). Berdasarkan hasil perhitungan yang dilakukan dengan aplikasi SPSS 21.0, Pengujian multikolinearitas pada penelitian ini ditunjukkan pada tabel 4.12 sebagai berikut :

Tabel 4.12

\section{Hasil Uji Multikolineritas}

\begin{tabular}{|c|c|c|c|}
\hline Variabel Bebas & Tolerance Value & VIF & Keterangan \\
\hline Pelatihan $\left(\mathrm{X}_{1}\right)$ & 0,811 & 1.234 & Nonmultikoneritas \\
\hline Motivasi Kerja $\left(\mathrm{X}_{2}\right)$ & 0,658 & 1.519 & Nonmultikoneritas \\
\hline Lingkungan Kerja $\left(\mathrm{X}_{3}\right)$ & 0,692 & 1.444 & Nonmultikoneritas \\
\hline
\end{tabular}

\section{Sumber: Lampiran 4}

Dari hasil pengelolaan data diperoleh nilai tolerance value Pelatihan, Motivasi Kerja, serta Lingkungan Kerja menunjukan 0,811, 0,658, 0,692 (lebih besar dari) > 0,1, dan nilai VIF 1,234, 1,519, 1,444, (lebih kecil dari) < 10, maka dapat disimpulkan bahwa tidak terjadi kolerasi di antara variabel-variabel independent yang di uji.

\section{Uji Heterokedastisitas}

Untuk melihat adanya heterokedastisitas adalah dengan menggunakan uji statistik. Uji statistik yag dipilih adalah uji Glejser, dasar pengambilan keputusan uji heteroskedastisitas 
melalui uji Glejser adalah apabila hasil sig $>0,05$ maka tidak terdapat gejala heteroskedastisitas (Ghozali 2016:134). Berikut ini hasil statistik dapat dilihat di Tabel 4.13 :

Tabel 4.13

\section{Uji Heteroskedastisistas}

\begin{tabular}{|l|c|l|}
\hline \multicolumn{1}{|c|}{ Variabel } & Sig & \multicolumn{1}{c|}{ Kesimpulan } \\
\hline Pelatihan $\left(\mathrm{X}_{1}\right)$ & 0,368 & Tidak terdapat gejala heteroskedastisitas \\
\hline Motivasi Kerja $\left(\mathrm{X}_{2}\right)$ & 0,118 & Tidak terdapat gejala heteroskedastisitas \\
\hline Lingkungan Kerja $\left(\mathrm{X}_{3}\right)$ & 0,386 & Tidak terdapat gejala heteroskedastisitas \\
\hline
\end{tabular}

Sumber : Lampiran 4 (2020)

Berdasarkan Tabel 4.12 diatas menunjukan bahwa nilai uji Glejser Pelatihan $\left(\mathrm{X}_{1}\right)$ 0,368, Motivasi Kerja $\left(\mathrm{X}_{2}\right)$ 0,118, Lingkungan Kerja $\left(\mathrm{X}_{3}\right)$ 0,386. Hal tersebut menunjukan bahwa tidak terdapat gejala heteroskedastisitas karena hasil sig. > 0,05.

\section{Analisis Regresi Berganda}

Tabel

Uji Regresi Linear Berganda

\section{Coefficients $^{\mathrm{a}}$}

\begin{tabular}{|c|c|c|c|c|c|c|}
\hline \multirow{2}{*}{\multicolumn{2}{|c|}{ Model }} & \multicolumn{2}{|c|}{$\begin{array}{l}\text { Unstandardized } \\
\text { Coefficients }\end{array}$} & \multirow{2}{*}{\begin{tabular}{|l} 
Standardiz \\
ed \\
Coefficient \\
s \\
Beta
\end{tabular}} & \multirow[t]{2}{*}{$t$} & \multirow[t]{2}{*}{ Sig. } \\
\hline & & $B$ & Std. Error & & & \\
\hline \multirow{4}{*}{1} & (Constant) & .036 & 1.917 & & .019 & .985 \\
\hline & Pelatihan & .205 & .082 & .255 & 2.485 & .015 \\
\hline & Motivasi & .208 & .088 & .270 & 2.373 & .020 \\
\hline & $\begin{array}{l}\text { Lingkungan } \\
\text { Kerja }\end{array}$ & .184 & .077 & .264 & 2.383 & .020 \\
\hline
\end{tabular}

a. Dependent Variable: Kinerja Guru

\section{Sumber Lampiran 4 (2020)}

Dari Tabel 4.13 persamaan regresi Linear Berganda diatas dapat diperoleh persamaan Linear berganda adalah sebagai berikut : 


$$
Y=0,036+0,205 X_{1}+0,208 X_{2}+0,184 X_{3}+e
$$

Berdasarkan Tabel 4.13, maka dapat diperoleh persamaan regresi linier berganda adalah sebagai berikut :

1. Nilai konstanta sebesar 0,036 artinya menunjukkan apabila Variabel Pelatihan $\left(\mathrm{X}_{1}\right)$, Motivasi Kerja $\left(\mathrm{X}_{2}\right)$, Lingkungan Kerja $\left(\mathrm{X}_{3}\right)$, bernilai 0, maka nilai variabel Kinerja (Y) adalah 0,036 .

2. Koefisien regresi Variabel Pelatihan $\left(X_{1}\right)$ sebesar 0,205 artinya jika Pelatihan $\left(X_{1}\right)$ berubah, maka Kinerja (Y) meningkat sebesar 0,282 dengan anggapan Motivasi Kerja $\left(\mathrm{X}_{2}\right)$, Lingkungan Kerja $\left(\mathrm{X}_{3}\right)$ bernilai tetap.

3. Koefisien regresi Motivasi Kerja (b) sebesar 0,208 artinya jika Lingkungan Kerja ( $\left.\mathrm{X}_{3}\right)$ berubah, maka Kinerja (Y) meningkat sebesar 0,208 dengan anggapan Pelatihan $\left(\mathrm{X}_{1}\right)$, Lingkungan Kerja $\left(\mathrm{X}_{3}\right)$ bernilai tetap.

\section{Koefisien Determinasi}

Koefisien korelasi (R) digunakan untuk mengetahui hubungan antar variabel bebas (X) terhadap variabel terikat (Y) secara bersama. Koefisien determinasi (R2) pada intinya mengukur seberapa jauh kemampuan model dalam menerangkan variasi variabel independent. Koefisien determinasi (R2) dapat dilihat pada Tabel 4.15 berikut ini :

Tabel 4.15

\section{Uji Koefisien Determinasi}

Model Summary

\begin{tabular}{|l|l|r|l|r|}
\hline Model & $R$ & R Square & $\begin{array}{l}\text { Adjusted R } \\
\text { Square }\end{array}$ & Std. Error of the Estimate \\
\hline 1 & $.622^{\mathrm{a}}$ & .387 & .361 & 1.114 \\
\hline
\end{tabular}

a. Predictors: (Constant), Lingkungan Kerja, Pelatihan, Motivasi

b. Dependent Variable: Kinerja Guru

\section{Sumber : Lampiran 4}

Berdasarkan hasil koefisien determinasi diatas, besarnya Adjusted $R$ Square adalah 0,361. Dapat dikatakan bahwa perubahan variabel dependen Kinerja Guru (Y) sebesar 0,361 atau $36,1 \%$ terhadap variabel Pelatihan $\left(\mathrm{X}_{1}\right)$, Motivasi Kerja $\left(\mathrm{X}_{2}\right)$, Lingkungan Kerja $\left(\mathrm{X}_{3}\right)$, sedangkan sisanya $63,9 \%$ disebabkan oleh faktor lain yang tidak diterangkan dalam model ini.

\section{Uji Hipotesis}

Hipotesis penelitian ini adalah pengaruh secara parsial variabel Pelatihan $\left(\mathrm{X}_{1}\right)$, 
Motivasi Kerja $\left(\mathrm{X}_{2}\right)$, Lingkungan Kerja $\left(\mathrm{X}_{3}\right)$, terhadap kinerja $(\mathrm{Y})$. Pengujian hipotesis ini dilakukan dengan Teknik statistic uji t (parsial).

Tabel 4.15

Hasil Analisis Koefisien Parsial (Uji t)

Coefficients $^{\mathrm{a}}$

\begin{tabular}{|c|c|c|c|c|c|c|}
\hline \multirow{2}{*}{\multicolumn{2}{|c|}{ Model }} & \multicolumn{2}{|c|}{$\begin{array}{l}\text { Unstandardized } \\
\text { Coefficients }\end{array}$} & \multirow{2}{*}{\begin{tabular}{|l} 
Standardiz \\
ed \\
Coefficient \\
S \\
Beta
\end{tabular}} & \multirow[t]{2}{*}{$\mathrm{t}$} & \multirow[t]{2}{*}{ Sig. } \\
\hline & & $B$ & Std. Error & & & \\
\hline \multirow{5}{*}{1} & (Constant) & .036 & 1.917 & & .019 & .985 \\
\hline & Pelatihan & .205 & .082 & .255 & 2.485 & .015 \\
\hline & Motivasi & .208 & .088 & .270 & 2.373 & .020 \\
\hline & Lingkungan & .184 & .077 & .264 & 2.383 & .020 \\
\hline & Kerja & & & & & \\
\hline
\end{tabular}

\section{Interprestasi Hasil}

\section{Pengaruh Pelatihan Terhadap Kinerja Guru}

Sesuai dengan jawaban responden yang menyatakan setuju terhadap instruktur, peserta pelatihan, metode materi, tujuan pelatihan. Jadi dapat disimpulkan bahwa pelatihan dapat mempengaruhi Kinerja Guru. Hasil penelitian terhadap variabel Pelatihan $\left(\mathrm{X}_{1}\right)$ diperoleh nilai $t_{\text {hitung }}$ sebesar 2,485> $t_{\text {tabel }}$ 1,9935, dengan tingkat signifikansi sebesar 5\%, maka terbukti bahwa secara parsial variabel Pelatihan $\left(\mathrm{X}_{1}\right)$ diterima. Dengan demikian dapat dikatakan terbukti berpengaruh positif terhadap kinerja (Y) Yayasan AL-Muniroh Ujung Pangkah Gresik. Hal ini sesuai dengan pendapat. Nawari (2011:208) bahwa pelatihan merupakan Tujuan utama untuk melengkapi kemampuan kerjanya, agar mampu, agar mampu 
melaksanakan tugas tugas secara efektif dan efisien. Kinerja guru menjadi tolak ukur dari keberhasilan sekolah dalam mencerdaskan dan membentuk karakter. Hal ini diperkuat dengan penelitian yang dilakukan, Sulasmono (2017). Sehingga hubungan Pelatihan dengan kinerja guru adalah positif.

\section{Pengaruh Motivasi Kerja Terhadap Kinerja Guru}

Sesuai dengan responden yang menyatakan setuju terhadap fisiologis dan kebutuhan fisik, keamanan, sosial, pengjargaan, akualisasi diri. Jadi dapat disimpulkan bahwa Motivasi kerja dapat mempengaruhi Kinerja Guru. Hasil penelitian terhadap variabel Motivasi Kerja $\left(\mathrm{X}_{2}\right)$ diperoleh $t_{\text {hitung }}$ sebesar 2,373> $t_{\text {tabel }}$ sebesar 1,9935, dengan tingkat signifikansi sebesar 5\%. Maka terbukti Motivasi Kerja $\left(\mathrm{X}_{2}\right)$ diterima. Dengan demikian dapat dikatakan bahwa secara variabel Motivasi Kerja $\left(\mathrm{X}_{2}\right)$ berpengaruh positif signifikasi terhadap kinerja (Y) Yayasan AL-Muniroh Pangkah Gresik. Hal ini sesuai dengan pendapat, hasil penelitian ini konsisten dengan teori yang dikemukakan oleh Darojat (2015:187) bahwa Motivasi merupakan daya dorong yang mengakibatkan seorang pegawai mau dan rela dalam mengarahkan kemampuanya secara maksimal dalam mengembangkan tanggung jawab untuk pencapaian tujuan dari organisasi guna meningkatkan kinerja. Hal ini diperkuat dengan penelitian yang dilakukan, Ardiana (2017) yang menunjukan bahwa motivasi kerja berhubungan positif terhadap Kinerja Guru SMK kota Madiun.

\section{Pengaruh Lingkungan Kerja Terhadap Kinerja Guru}

Sesuai dengan jawaban responden yang menyatakan bahwa setuju terhadap penerangan yang cukup, sirkulasi udara yang baik, keberhasilan yang terpelihara dengan baik. Jadi dapat disimpulkan bahwa Lingkungan Kerja dapat mempengaruhi Kinerja Guru. Hasil penelitian terhadap variabel Lingkungan Kerja $\left(\mathrm{X}_{3}\right)$ diperoleh $t_{\text {hitung }}$ sebesar 2,383 > $t_{\text {tabel }}$ sebesar 1,9935, dengan tingkat signifikansi sebesar 5\%. Maka terbukti Lingkungan Kerj $\left(\mathrm{X}_{3}\right)$ diterima. Dengan demikian dapat dikatakan bahwa secara variabel Lingkungan Kerja $\left(\mathrm{X}_{3}\right)$ berpengaruh positif signifikasi terhadap kinerja $(\mathrm{Y})$ Yayasan AL-Muniroh Pangkah Gresik. Hal ini sesuai dengan pendapat Menurut pendapat, Afandi (2016;51), dimana dalam lingkungan kerja tersebut terdapat fasilitas kerja yang mendukung dalam penyelesaian tugas yang bebankan kepada guru guna meningkatkan kinerja. Lingkungan kerja yang baik, kondusif, nyaman, aman, bersih dan tenteram tentu akan menimbulkan atau meningkatkan semangat kerja. Untuk itu, sekolah perlu memperhatikan dan bertindak bijak agar lingkungan kerja dapat memberikan dampak positif bagi kemajuan sekolah. Hal ini diperkuat dengan 
penelitian yang dilakukan, Eliyanto (2018) di Kabupaten Kebumen yang menunjukan bahwa Lingkungan Kerja berhubungan positif terhadap Kinerja Guru.

\section{Kesimpulan Dan Rekomendasi}

\section{Simpulan}

Berdasarkan hasil pengolahan data dalam penelitian ini dapat ditarik kesimpulan sebagai berikut :

1. Pelatihan berpengaruh signifikan secara parsial terhadap Kinerja Guru Yayasan ALMuniroh Ujung Pangkah Gresik.

2. Motivasi Kerja berpengaruh signifikan seara parsial terhadap Kinerja Guru Yayasan AL-Muniroh Ujung Pangkah Gresik.

3. Lingkungan Kerja berpengaruh signifikan secara parsial terhadap Kinerja Guru Yayasan AL-Muniroh Ujung Pangkah Gresik.

\section{Rekomendasi}

Berdasarkan hasil analisis, pembahasan dan kesimpulan penelitian, maka rekomendasi dari penelitian dapat diberikan sebagai berikut :

1. Bagi sekolahan harus mampu meningkatkan Pelatihan, Motivasi Kerja, Lingkungan Kerja, agar Kinerja Guru di Yayasan AL-Muniroh Ujung Pangkah Gresik mengalami peningkatan.

a. Variabel Pelatihan $\left(\mathrm{X}_{1}\right)$, Motivasi Kerja $\left(\mathrm{X}_{2}\right)$, Lingkungan Kerja $\left(\mathrm{X}_{3}\right)$, memiliki nilai $t_{\text {hitung }}$ lebih tinggi maka sekolahan supaya tetap mempertahankan dan terus meningkatkan agar kinerja guru di Yayasan AL-Muniroh Ujung Pangkah Gresik mengalami peningkatan.

b. Dilihat dari uji t bahwa variabel Motivasi Kerja $\left(\mathrm{X}_{2}\right)$, memiliki nilai $t_{\text {hitung }}$ terendah dari pada variabel Pelatihan $\left(\mathrm{X}_{1}\right)$, serta Lingkungan Kerja $\left(\mathrm{X}_{3}\right)$. Maka, sebaliknya pihak atasan melakukan sosialisasi mengenai Yayasan AL-Munieoh Ujung Pangkah Gresik dan memberikan reward kepada guru yang berprestasi agar termotivasi sehingga kinerja karyawan akan terus meningkat.

2. Bagi Peneliti Selanjutnya

a. Bagi peneliti selanjutnya hasil penelitian ini dapat digunakan sebagai refrensi dua selanjutnya dengan menambah jumlah variabel atau fenomena dilapangan dengan melihat hal-hal yang dapat mempengaruhi kinerja. Misalnya disiplin kerja, keterampilan, budaya organisasi, dan kepuasan kerja dll. Selain itu, dapat 
menggunakan teknik analisis dan metode yang berbeda-beda untuk mengetahui perbedaan analisis satu dengan analisis yang lainya.

\section{Daftar Pustaka}

Afandi, Pandi. 2016. Concept \& Indicator Human Resource Management. Yogyakarta: Deepublish

Hadari Nawari, 2011. Manajemen Sumber Daya Manusia. Yogyakarta, Cetakan Kedelapan, P.O. Box 14, Bulaksumur

Slameto, Bambang S.Sulasmono, Krisma Wardani, 2017. Peningkatan Kinerja Guru Melalui Pelatihan Beserta Faktor Penentunya. Jurnal Pendidikan Ilmu Sosial, Vol 27, No.2

Eliyanto, 2018. Pengaruh Motivasi Kerja dan Lingkungan Kerja Terhadap Kinerja Guru SMA Muhamadiyah di Kabupaten Kebumen. Jurnal Pendidikan Madrasah, Volume 3, Nomor 1.

Ardiana Eka Titin, 2017. Pengaruh Motivasi Kerja Guru Terhadap Kinerja Guru Akuntansi SMK di Kota Madiun. Jurnal Akuntansi dan Pajak, Vol 17, No 02.

Subhan Adi Santoso, Maulidyah Amalina Rizqi 2020. Kinerja Pengawas Sekolah, Kepala Sekolah, dan Guru pada Pendidikan. Yogyakarta: Deepublish

Slameto, Bambang S.Sulasmono, Krisma Wardani, 2017. Peningkatan Kinerja Guru Melalui Pelatihan Beserta Faktor Penentunya. Jurnal Pendidikan Ilmu Sosial, Vol 27, No.2 